\title{
UPAYA GURU BK DALAM MENANGANI PERILAKU AGRESIF SISWA DI SMP NEGERI 12 TARAKAN
}

\author{
Usnul Wardani, Hendra Pribadi \\ Fakultas Keguruan dan Ilmu Pendidikan, Universitas Borneo Tarakan \\ usnul.wardhani@gmail.com
}

\begin{abstract}
Adolescence is a human life span, where adolescents experience development in physical, mental, social, and emotional maturity so that they tend to accentuate negative behavior, one of which is aggressive behavior. To overcome this behavior, the teacher's guidance and counseling efforts are very important. The formulation of the problem in this study is how the teacher's guidance and counseling efforts in dealing with aggressive behavior. The purpose of this study was to find out how the teacher's guidance and counseling efforts in dealing with aggressive behavior of students in SMP Negeri 12 Tarakan.

This type of research is descriptive qualitative research. The informants in this study were principals, BK teachers and students. Research instruments are observation, interviews, and documentation. The results showed that (1) the cause of students behaving aggressively is mostly because they have not been able to control emotions, the character of students is hard, and tend to assume that the behavior they do is reasonable and because of lack of supervision, attention and affection from parents so that children tend to feel able to do anything cool and (2) the efforts of $B K$ teachers in dealing with aggressive behavior of students is quite good by providing individual counseling services, group counseling services, conducting home visits, working with parents and homerooms in monitoring student changes.
\end{abstract}

Keywords: Teacher, Guidance and Counseling, Aggressive Behavior

\section{PENDAHULUAN}

Masa remaja merupakan rentang kehidupan manusia. Remaja mengalami perkembangan pada kematangan fisik, mental, sosial, dan emosional. Ali dan Asrori (2014) menyatakan bahwa remaja memiliki energi yang besar, emosi berkobar-kobar, namun pengendalian diri belum sempurna. Remaja dikenal dengan fase 'topan dan badai' karena belum menguasai fungsi fisik maupun psikis. Remaja cenderung menonjolkan perilaku yang negatif, salah satunya adalah perilaku agresif.

Perilaku agresif merupakan tindakan sengaja menyerang, menyakiti seseorang secara verbal maupun fisik. Bentuk fisik seperti memukul, menendang, melempar, merusak, dan bentuk lain yang mengakibatkan sakit/luka secara fisik. Sedangkan bentuk verbal seperti, mencaci maki, berteriak, melontarkan kata-kata kasar (Mifzal, 2013).
Siswa berperilaku agresif karena menganggap wajar dan tidak menyakiti perasaan serta fisik orang lain. Siswa yang

berperilaku agresif dapat menghambat pembentukan kepribadian, aktualisasi diri dalam meraih prestasi di sekolah, dan dikhawatirkan menimbulkan masalah lain, seperti tidak diterima teman-temannya (dimusuhi, dijauhi, tidak diajak bermain) dan dianggap pembuat masalah oleh guru. Hasil penelitian yang dilakukan oleh Rina

(2011) tentang faktor yang melatarbelaka ngi perilaku agresif pada remaja, menunjukkan dari jumlah responden sebanyak 103 orang, mayoritas remaja laki-laki berperilaku agresif sebanyak 66 orang $(66.02 \%)$, sedangkan remaja perempuan setengah dari remaja lakilaki yaitu sebanyak 35 orang (33.98\%). Hasil penelitian tersebut memberikan gambaran bahwa remaja masih berperilaku agresif, 
apabila hal tersebut dibiarkan, maka akan membawa dampak besar bagi kehidupan remaja

Berdasarkan penjelasan diatas dan hasil observasi awal yang dilakukan di SMP Negeri 12 Tarakan, bahwa sebagian besar siswa masih berperilaku agresif. Uniknya, siswa perempuan terlihat lebih agresif dibandingkan siswa laki-laki. Perilaku yang terlihat adalah sering merampas milik orang lain, main perintah, bersorak atau berteriak dengan keras tanpa melihat situasi dan kondisi. Perilaku agresif tidak hanya dilakukan kepada teman saja, namun juga kepada guru seperti melawan, tidak menaati perintah, mencemoh guru ketika belajar. Hal ini juga dikuatkan hasil wawancara penulis dengan guru bimbingan dan konseling SMP Negeri 12 Tarakan pada tanggal 21 Januari 2018, bahwa ada tindakan agresif yang mengakibatkan rusaknya fasilitas sekolah.

Berdasarkan berbagai macam pendapat diatas dapat dipahami bahwa bentuk perilaku agresif terbagi menjadi agresif secara fisik dan verbal. Untuk mengatasi perilaku tersebut maka upaya guru bimbingan dan konseling disekolah penting. Guru bimbingan dan konseling mempunyai tanggung jawab sebagai tenaga kependidikan sesuai bidangnya yaitu memberikan pelayanan bimbingan dan konseling kepada siswa. Bimbingan tidak diberikan kepada siswa yang bermasalah saja, setiap siswa mempunyai hak mendapatkan bimbingan. Salah satu tujuan bimbingan kepada siswa berdasarkan aspek pribadi-sosial agar siswa memiliki sikap positif atau respect terhadap diri sendiri dan orang lain. Guru bimbingan dan konseling dapat memberikan beberapa layanan: 1) Layanan informasi, merupakan layanan penyampaian informasi yang digunakan sebagai bahan perimbangan dan pengambilan keputusan untuk kepentingan siswa, pemecahan masalah, mencgeah masalah, mengembangkan serta memelihara potensi. Pembentukan sikap, perilaku positif siswa dapat dilakukan dengan memberikan layanan informasi mengenai perilaku agresif dan sangsi yang diperoleh apabila melakukannya. Layanan ini dapat di berikan secara kelompok dan individual; 2) Layanan konseling individual merupakan layanan yang memungkinkan siswa mendapatkan layanan tatap muka secara perorangan dengan guru bimbingan dan konseling, untuk memecahkan masalah pribadi. Melalui layanan ini guru bimbingan dan konseling dapat membantu siswa yang mengalami masalah menyangkut perilaku agresif (Hidayat, Yusri, \& Ilyas, 2015).

Berdasarkan pengamatan saat observasi awal menunjukkan guru bimbingan dan konseling di SMP Negeri 12 Tarakan telah menangani perilaku agresif dengan memberikan salah satu layanan bimbingan dan konseling yaitu layanan konseling individual. Upaya guru bimbingan dan konseling disekolah khususnya di SMP Negeri 12 Tarakan dapat dikatakan penting, karena ketika siswa berperilaku agresif, guru mata pelajaran hanya menegur siswa dan menyerahkan tanggung jawab kepada guru bimbingan dan konseling. Untuk itu, maka penulis ingin mengetahui secara mendalam mengenai upaya apa yang telah dilakukan oleh guru bimbingan dan konseling, yang berifat preventif, kuratif, dan pembinaan dalam menangani perilaku agresif siswa. Berdasarkan uraian latar belakang diatas, maka penulis tertarik untuk mengkaji lebih dalam mengenai "Upaya Guru Bimbingan dan Konseling Dalam Menangani Perilaku Agresif Siswa di SMP Negeri 12 Tarakan"

\section{METODE PENELITIAN}

Penelitian ini dilaksanakan untuk mengungkap dan menjelaskan tentang upaya yang dilakukan oleh guru BK dalam menangani perilaku agresif siswa. Berdasarkan fokus masalah tersebut, jenis penelitian yang digunakan adalah penelitian kualitatif yang bersifat deskriptif yaitu menggambarkan fenomena atau peristiwa yang terjadi pada situasi-situasi tertentu, berupa upaya preventif, kuratif, dan pembinaan dalam menangani perilaku agresif siswa di SMP Negeri 12 Tarakan.

Menurut Prastowo (2016) adapun yang dimaksud dengan metode penelitian kualitatif adalah penelitian yang sistematis dan digunakan untuk mengkaji atau meneliti suatu objek pada latar alamiah tanpa ada manipulasi didalamnya dan tanpa ada pengujian hipotesis. Penelitian ini menggunakan pendekatan studi kasus, dengan tujuan menemukan fakta tentang 
bagaimana upaya yang dilakukan oleh guru BK dalam menangani perilaku agresif siswa SMP Negeri 12 Tarakan. Bogdan \& Biklen (dalam Ahmadi, 2014) mengatakan bahwa studi kasus adalah suatu kajian yang rinci tentang satu latar belakang atau subjek tunggal, atau suatu tempat penyimpanan dokumen, atau suatu peristiwa tertentu.

\section{INFORMAN PENELITIAN}

Informan penelitian terbagi menjadi dua, yaitu informan utama dan informan biasa. Informan utama dalam penelitian ini adalah guru BK, sedangkan informan biasa dalam penelitian ini adalah kepala sekolah, dan siswa SMP Negeri 12 Tarakan. Adapun penentuan informan dalam penelitian ini menggunakan purposive sampling.

Purposive sampling merupakan salah satu teknik pengambilan sampel yang sering digunakan dalam penelitian kualitatif. Sugiyono (2015) berpendapat bahwa purposive sampling adalah teknik pengambilan sampel sumber data dengan pertimbanganpertimbangan tertentu, misalnya orang yang dianggap paling tahu tentang apa yang kita harapkan, orang yang menjadi pemimpin atau penguasa sehingga akan memudahkan penulis menjelajahi objek/situasi sosial yang akan diteliti.

\section{TEKNIK ANALISIS DATA}

Penelitian ini menggunakan pendekatan kualitatif, maka teknik analisis data yang digunakan adalah teknik analisis kualitatif. Menurut Sugiyono (2015) analisis data adalah proses mencari dan menyusun secara sistematis data yang diperoleh dari hasil wawancara, catatan lapangan, dan dokumentasi, dengan cara mengorganisasikan data kedalam kategori, menjabarkan kedalam unit-unit, melakukan sintesa, menyusun kedalam pola, memilih mana yang penting dan yang akan dipelajari, dan membuat kesimpulan sehingga mudah dipahami oleh diri sendiri maupun orang lain. Menurut Miles dan Huberman (dalam Sugiyono, 2015) terdapat 3 tahap analisis data, yaitu: 1) Reduksi data; 2) Display data; 3) Verifikasi dan kesimpulan.

\section{HASIL DAN PEMBAHASAN}

Perilaku agresif yang ditunjukkan siswa adalah dalam bentuk perilaku agresif verbal dan fisik. Dalam bentuk perilaku agresif verbal, siswa menunjukkannya dengan menganggap dirinya yang paling benar, melontarkan kata-kata yang tidak baik, menyindir teman dengan tujuan menyakiti hati dan perasaan orang lain, membentak dan memarahi orang lain didepan orang banyak sehingga tidak jarang membuat orang lain tersinggung, sedangkan untuk perilaku agresif fisik ditunjukkan dengan menggangu teman yang mengerjakan tugas, melakukan tindakan fisik seperti mencubit, memukul, mendorong, dan menarik-narik baju teman, terlibat perkelahian, serta melampiaskan rasa marah dengan memukul meja atau fasilitas kelas.

Penyebab perilaku agresif yang ditunjukkan oleh siswa adalah sebagian besar karena karakter siswa yang keras dan cenderung mengangap bahwa perilaku yang mereka lakukan adalah sebuah kewajaran, mereka cenderung menganggap bahwa apa yang mereka lakukan hanya lah bentuk candaan yang tidak akan menyakiti perasaan dan fisik orang lain tanpa merpertimbangkan akibat dari perbuatan tersebut. Selanjutnya, karena kurangnya pengawasan, perhatian dan kasih sayang dari orang tua sehingga anak cenderung merasa dapat melakukan apapun yang ia inginkan tanpa merasa takut ditegur dan dimarahi.

Upaya guru bimbingan dan konseling dalam menangani perilaku agresif siswa adalah dengan memberikan layanan konseling individual, layanan konseling kelompok, home visit, bekerjasama dengan orang tua siswa, bekerjasama dengan wali kelas. Siswa yang menunjukkan perilaku agresif di panggil ke ruang $\mathrm{BK}$, diberikan pengarahan dan nasehat agar dapat mengubah perilakunya tersebut yang menyakiti dan merugikan orang lain maupun dirinya sendiri. Apabila siswa tidak menunjukkan perubahan atau masih saja berbuat demikian, guru bimbingan dan konseling mengambil tindakan untuk memanggil orang tua siswa agar dapat mengkomunikasikan dan mencari solusi dari masalah yang di hadapi oleh siwa tersebut. 


\section{KESIMPULAN}

Berdasarkan hasil penelitian dan pembahasan, diambil kesimpulan sebagai berikut:

1. Memberikan layanan konseling individual atau konseling kelompok kepada siswa yang terdeteksi berperilaku agresif dengan cara menerima siswa dengan baik, tanpa menjudge dan memarahi siswa karena perilaku agresifnya.

2. Guru BK mendengarkan siswa bercerita mengenai penyebab dan alasan mereka berperilaku agresif. Setelah itu guru BK akan mengarahkan siswa dan melakukan pembiasaan dengan siswa untuk berubah, agar tidak lagi mengulangi perilaku agresif tersebut. Guru BK akan terus mem follow up atau memantau perkembangan siswa apakah telah berubah menjadi lebih baik atau tidak.

3. Melakukan layanan home visit atau kunjungan ke rumah siswa untuk melakukan konsultasi dengan orang tua, serta mengajak orang tua siswa untuk bekerjasama dalam memantau perubahan siswa agar menjadi pribadi yang lebih baik, dengan tujuan agar hubungan komunikasi antara guru dan orang tua terjalin dengan baik.

4. Guru BK bekerja sama dengan wali kelas dalam menangani siswa yang berperilaku agresif dengan menerapkan treatment pembiasaan didalam kelas apabila siswa kembali melakukan perilaku agresif.

\section{DAFTAR PUSTAKA}

Ahmadi, R. 2016. Metode Penelitian Kualitatif. Yogyakarta: Ar-Ruzz Media.

Ali, M \& Asrori, M. 2014. Psikologi Remaja. Jakarta: PT. Bumi Aksara.

Damayanti, R., \& Aeni, T. Efektivitas Konseling Behavioral Dengan Teknik Modeling Untuk Mengatasi Perilaku Agresif Pada Peserta Didik Kelas VIII $B \quad S M P$ Negeri 7 Bandar Lampung. Jurnal Bimbingan dan Konseling, 3 (1): 97-112.

Dayakisni, T., \& Hudaniah. 2012. Psikologi Sosial. Malang: UMM Press.

Hayati, F. 2016. Peran Guru Bimbingan dan Konseling Dalam Mengatasi
Kecenderungan Perilaku Agresif Peserta Didik di MA. Jurnal Psikologi, 10 (6): 603-607.

Hidayat, H., Yusri, \& Ilyas, A. 2015. Profil Siswa Agresif dan Peranan Guru BK. Konselor, 4 (4): 196-199

Hikmawati, F. 2014. Bimbingan dan Konseling. Jakarta: PT. RajaGrafindo Persada.

Ibrahim, 2015. Metode Penelitian Kualitatif Panduan Penelitian Beserta Contoh Proposal. Bandung: Alfabeta.

Irham, M., \& Wiyani, N.A. 2014. Bimbingan dan Konseling Teori Aplikasi di Sekolah Dasar. Yogyakarta: Ar-Ruzz Media

Komalasari, G., Wahyuni, E., Karsih. 2011. Teori dan Teknik Konseling. Jakarta: PT. Index.

Ma'ruf, H. 2015. Perilaku Agresi Relasi Siswa di Sekolah. Yogyakarta: Aswaja Pressindo.

Mifzal, A. 2013. Strategi Pembelajaran Untuk Anak Kurang Berprestasi. Yogyakarta: Javalitera.

Prastowo, A. 2016. Metode Penelitian Kualitatif dalam Perspektif Rancangan Penelitian. Jogjakarta: ArRuzz Media.

Prayitno. 2017. Konseling Profesional yang Berhasil: Layanan Bimbingan dan Konseling. Jakarta: PT. Rajagrafindo.

Prayitno, \& Amti, E. 2015. Dasar-Dasar Bimbingan dan Konseling. Jakarta: Rineka Cipta

Rina. 2011. Faktor- Faktor yang Melatar belakangi Perilaku Agresif Pada Remaja Kelas II,III di SMP Pahlawan Toha Bandung 18 September 2006-05 Januari 2007. Jurnal Kesehatan Prima, 3 (2): 1424.

Siddiqah, L. 2010. Pencegahan dan Penanganan Perilaku Agresif Remaja Melalui Pengelolaan Amarah (Anger Management). Jurnal Psikologi, 37 (1): 50-64.

Sugiyono, 2015. Metode Penelitian Pendidikan (Pendekatan Kuantitatif, Kualitatif dan $R \& D)$. Bandung: Alfabeta 
Sukardi, D.K., \& Kusmawati, N. 2008. Proses Bimbingan dan Konseling di Sekolah. Jakarta: Rineka Cipta.

Willis, S.S. 2012. Remaja \& Masalahnya. Bandung: Alfabeta

Willis, S.S. 2014. Konseling Individual Teori dan Praktek. Bandung: Alfabeta

Winkel, W.S \& Hastuti Sri, M.M. 2004. Bimbingan dan Konseling di Institusi Pendidikan. Yogyakarta: Media Abadi

Yahya AD, Megalia. 2016. Pengaruh Konseling Cognitif Behavior Therapy (CBT) Dengan Teknik Self Control Untuk Mengurangi Perilaku Agresif Peserta Didik Kelas VIII di SMPN 9 Bandar Lampung Tahun Pelajaran 2016/2017. Jurnal Bimbingan dan Konseling, (2): 187200 